\title{
Dariusz Kotecki, Zrozumieć Apokalipsę? Szkice egzegetyczno- -teologiczne, Bonus Liber, Rzeszów 2021, ss. 294.
}

Krof. dr hab. Dariusz Kotecki to znany w środowisku naukowym Kopernika w Toruniu, zatrudnionym w Katedrze Teologii Historycznej. W 2021 roku nakładem wydawnictwa Bonus Liber ukazała się monografia ks. Koteckiego, poświęcona jednej z najtrudniejszych ksiąg biblijnych Apokalipsie św. Jana.

Na samym początku należy wspomnieć, że monografia ks. Dariusza Koteckiego należy do nowo powołanego zbioru Biblioteki Szkoły Dabar, której cykl publikacji ma służyć jako pomoc w uczestnictwie oraz lepszemu zrozumieniu warsztatów biblijno-teologiczno-archeologicznych organizowanych przez Instytut Nauk Biblijnych KUL, Stowarzyszenie na rzecz Wspierania Biblistyki „Verbum Sacrum” oraz Dom Diecezjalny „Tabor”. W przedmowie do monografii ks. Koteckiego znajdziemy kilka słów skierowanych przez ks. dra hab. Adama Kubisia, który -przywołując maksymę: Verba wolant, scripta manent (Słowa ulatują, to co zostało napisane pozostaje) - zaznacza, że zarówno warsztaty Szkoły Dabar, jak i towarzyszące im publikacje pomogą głębiej doświadczyć Słowa przeżytego w czasie spotkań oraz ułatwią powtórzenie przyswojonego materiału po ich zakończeniu ${ }^{1}$. Do zbioru Biblioteki Szkoły Dabar należy jeszcze wydana w 2021 roku monografia ks. Adama Kubisia pt. „Patmos. Geografia, Historia, Apokryfy".

W mowie wstępnej do swojej książki ks. Kotecki próbuje wprowadzić czytelnika w tajemniczy świat Apokalipsy. Przy badaniu tej najtrudniejszej księgi Nowego Testamentu egzegeci zadają wiele pytań - m.in. o rzeczywistość, która jest ukryta w charakterystycznych wyrażeniach księgi, takich

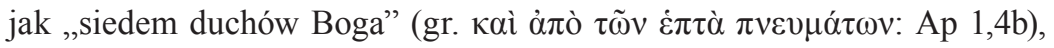

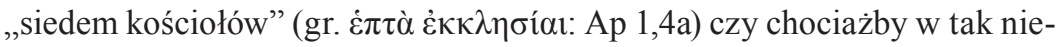

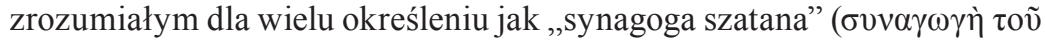

1 D. Kotecki, Zrozumieć Apokalipsę? Szkice egzegetyczno-teologiczne (Rzeszów: Bonus Liber 2021), 7. 


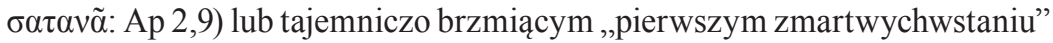

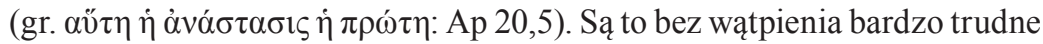
terminy, których znaczenie poznamy, zagłębiając się w tę monografię. Autor również zaznacza, że rynek wydawnictw naukowych przepełniony jest komentarzami skupiającymi się przede wszystkim na pojedynczych zagadnieniach czy krótkich teologicznych fragmentach Apokalipsy św. Jana, jednak ta monografia z cyklu Biblioteki Szkoły Dabar wprowadza czytelnika w tekst święty nie tylko poprzez reinterpretację Starego Testamentu, lecz również przez klucz teologiczny, którego kierunkiem i fundamentem są wydarzenia zbawcze w Jezusie Chrystusie.

Pierwszy rozdział został poświęcony zagadnieniom wstępnym, które wydają się być niezbędnym narzędziem przy pracy z każdą księga biblijną. Ks. Kotecki podkreśla tu wyjątkowy liturgiczny charakter Apokalipsy, cytując słowa Pierre’a Prigenta: „Apokalipsa wprost żywi się liturgią”. Objawia się to m.in. w języku kultycznym, którym dzieło janowe jest przepełnione. Uwidacznia się to w konkretnych terminach, takich jak ,pokłonić się”

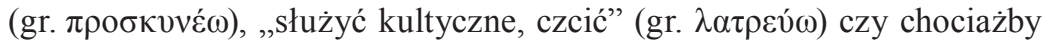
„śpiewać” (gr. oِ $\delta \omega)$. Autor zauważa, że liturgiczność Apokalipsy objawia się też w doksologiach $(4,11 ; 5,12)$, modlitwach dziękczynnych $(4,9 ; 5,12-13)$, hymnach (1,5b-6; 4,8c.11), czynnościach liturgicznych takich jak pokłony, granie na instrumentach muzycznych czy składanie ofiar kadzielnych. Oczywiście w pierwszym rozdziale znajdziemy również szereg informacji obejmujących gatunek literacki apokalipsy (s. 42-48), symbole i narzędzia komunikacji (s. 48-55), wspólnotę zanurzoną w swoim „tu” i „teraz” (s. 55-59), fundament teologiczny Apokalipsy, tj. proklamację dotyczącą historii (s. 59-61), oraz kilka słów o literackiej strukturze księgi (s. 61-64).

Drugi rozdział rozpoczyna typową egzegezę teologiczną, w której Autor stara się poruszyć najważniejsze wątki zawarte w Ap 1,1-8. To właśnie w tym rozdziale dowiadujemy się, że adresatami księgi jest „,siedem Kościołów, tych w Azji”. W wizji zawartej w Ap 1,9-20 wymienione wspólnoty nie pokrywają się z mapą geograficzną Azji Mniejszej, dlatego ks. Kotecki skłania się bardziej do symboliki liczby siedem użytej w tym fragmencie, która z racji swej pełni ma wskazywać bardziej na Kościół wszystkich czasów i miejsc, czyli na Kościół Powszechny. Zatem, „to co zostanie powiedziane do tych konkretnych siedmiu wspólnot jest obowiązujące dla Kościoła wszystkich miejsc i każdego czasu”. Niezwykle istotnym zagadnieniem jest też pytanie, do jakiego Jana Bóg posyła swego Anioła i jaki Jan ma być tym, który zaświadczy? Z omawianej monografii dowiemy się, że imię Jan pada w Apokalipsie 4 razy: trzy razy na początku księgi $(1,1.4 .9)$ oraz jeden raz na jej końcu $(22,8)$. Ks. Kotecki podaje dwa stanowiska, 
które należy tu rozważyć. Po pierwsze, jeżeli uznamy Apokalipsę za dzieło należące do zbiorów literatury apokaliptycznej, wówczas musimy zauważyć, że cechą charakterystyczną tego gatunku jest tzw. psedonimia lub też pseudoepigrafia. Zgodnie z tym założeniem to autor Apokalipsy podszywałby się pod Jana, syna Zebedeusza, autora Czwartej Ewangelii. Wiemy, że tak nie jest, choć istnieją też niezaprzeczalne fakty, o których trzeba powiedzieć. Mianowicie redakcja Apokalipsy nastąpiła w pierwszej połowie II wieku po Chr., kiedy św. Jan już nie żył. Choć sama księga jest dość spójna, to jednak nosi widoczne znamiona pracy redaktora. Wśród kandydatów na autora tego dzieła wymienia się św. Jana Ewangelistę, Jana Prezbitera lub Jana Proroka. Najpewniej jednak - zdaniem Autora - Apokalipsa jest dziełem pisarza pochodzącego ze środowiska janowego, jednak zagadnienie autorstwa i identyfikacji imienia z Ap 1,1.4.9 oraz 22,8 muszą pozostać nierozstrzygnięte.

Kolejny rozdział został zatytułowany „Spotkanie ze Zmartwychwstałym” i obejmuje analizę Ap 1,9-20. Autor zauważa, że właściwie w tym miejscu rozpoczyna się pierwsza część dzieła, do którego wlicza się wizja wstępna (1,9-20) oraz listy skierowane do siedmiu Kościołów $(2,1-3,2)$. Wspomniana wizja wstępna ma zostać spisana przez Jana - odbiorcę przesłania i wysłana do siedmiu Kościołów Azji Mniejszej. W tym miejscu Apokalipsa wymienia: Efez, Smyrnę, Pergamon, Tiatyrę, Sardy, Filadelfię i Laodyceę. Ten, który odbiera wizje, ma za zadanie nie tylko ją spisać. Ks. Kotecki zauważa, że otrzymane przesłanie dotyczy całej historycznej rzeczywistości, w której żyją wyznawcy Chrystusa. Są oni zachęcani, aby patrzeć w przyszłość, budując wszystko na fundamencie, jakim jest zmartwychwstały Pan. Dlatego też przesłanie Jana jest również swego rodzaju świadectwem tego wszystkiego, co sam przeżył, a co teraz ma zanieść do wszystkich chrześcijan.

Rozdziały IV i V to kolejno „Zmartwychwstały mówi do Kościołów” (Ap 2,1-3,22) oraz „Bóg, Baranek Boży i Duch Święty - Pan dziejów” (Ap 4,1-5,14). Pierwszy z wymienionych jest początkiem części epistolarnej na którą składa się siedem listów do Kościołów. Listy te mają podobny schemat oparty na sześciu elementach: adres, autoprezentacja osoby Chrystusa, sąd jakiego dokonuje Chrystus nad danym Kościołem, wezwanie rozpoczynające się od trybu rozkazującego (imperativus), obietnica dla zwycięzcy oraz wezwanie ogólne. Wszystkie listy przybierają charakter dialogu. Autor omawianej monografii zauważa, że w siedmiokrotnie padającej obietnicy

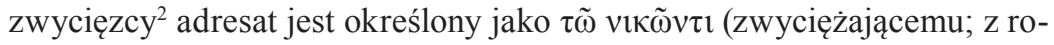




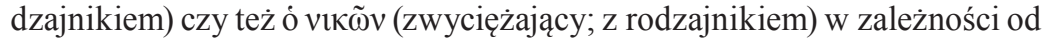
formy dawanej obietnicy. Użyte tutaj participium czasu teraźniejszego daje jasno do zrozumienia, że nie jest to zwycięstwo oparte na jednorazowym incydencie, lecz nieustannie powtarzane, przez co ma doprowadzić do konkretnej nagrody „mającej wymiar «wieczności»”. Obietnica ta pochodzi od Jezusa zmartwychwstałego, który sam jest zwycięzcą. Dalsza analiza tej części rozważań skupia się wokół poszczególnych siedmiu wspólnot i listów, które są do nich skierowane. W rozdziale $\mathrm{V}$ również wprowadzony jest nowy element, który tym razem rozgrywa się w kluczu prorockim - „to, co ma nastąpić”. Ma to oznaczać, że „w całej Apokalipsie chodzi o odczytanie teraźniejszości w perspektywie przyszłości”. O tym, że rozdział ten otwiera nową wizję, świadczy zwrot $\mu \varepsilon \tau \dot{\alpha} \tau \alpha \tilde{\tau} \tau \alpha$, czyli ,potem”. Znajdziemy tu wiele obrazów - m.in. przedstawienie tronu Bożego, który jest motywem przewodnim tego rozdziału, oraz całego jego otoczenia. Wszystkiemu towarzyszą zjawiska atmosferyczne podobne do tych ze Starego Testamentu, co obrazuje swoisty pomost między biblijnymi tradycjami. Niezwykle istotnym momentem jest summarium piątego rozdziału, czyli liturgia wszystkich istot żyjących oraz dwudziestu czterech starców. W liturgii tej biorą też udział niezliczone rzesze zastępów anielskich, które Apokalipsa wylicza jako „miriady miriad” oraz „tysiące tysięcy”. Ks. Kotecki zaznacza, że liczby te są bez wątpienia symbolami nieskończoności. „Miriady miriad” to 100.000 .000 , biorąc pod uwagę, że miriada to 10.000 , zaś „tysiące tysięcy” to 1.000 .000 . Mamy zatem do czynienia z nieskończoną liczbą tych, którzy wielbią Boga. Wydaje się, że jest to symbol całego stworzenia.

W kolejnym rozdziale Autor bierze na warsztat Ap 6,1-8,5. Jest to tzw. sekcja pieczęci, czyli moment otwierania przez Baranka kolejnych pieczęci. To właśnie w tym fragmencie, opisującym otwarcie czterech pierwszych pieczęci, pojawiają się tajemniczy czterej jeźdźcy Apokalipsy, w których wielu egzegetów nadal upatruje symbole przeróżnych plag dotykających ludzkość. Auto zauważa również, że nie brak badaczy, którzy dostrzegają w nich aluzję do Za 1,11-17 i 6,1-8, gdzie mówi się o czterech rydwanach wiatru mających cztery różne maści, które w imieniu Pana okrążają całą ziemię. Ks. Kotecki interpretuje czterech jeźdźców jako pewien symbol powtarzających się wydarzeń. Koń ognisty, czarny i trupio blady są symbolami wojen, niesprawiedliwości i przemocy, które były, są i będą elementami towarzyszącymi ludzkości. Jednak w obliczu tych nieszczęść pojawia się koń biały, który jest symbolem Chrystusa, zbawcy i wybawiciela człowieka. To właśnie w Nim powinien pokładać nadzieję każdy człowiek, który jako wyznawca Jezusa staje się ,uobecnieniem Jego zwycięstwa w misterium paschalnym”. Dalsza część VI rozdziału to analiza kolejnych łamanych 
przez Baranka pieczęci oraz wniosek, w którym Autor suponuje objawienie się sensu całej historii człowieka, którym jest Dzień Pański. Wszyscy ci, którzy go wyczekują, otwierają się na ożywiające działanie Boga, który „jest gwarantem dojścia do nieba".

W tym miejscu chciałbym od razu przejść do rozdziału VIII, który poświęcony jest fragmentowi Ap 12,1-16,21. W znacznej części Autor skupia się na analizie fragmentu opisującego Niewiastę i smoka, który znamy chociażby z liturgii 15 sierpnia, czyli Uroczystości Wniebowzięcia NMP. Obraz Niewiasty jest - zdaniem ks. Koteckiego - z jednej strony ukierunkowany eklezjologiczne, zaś z drugiej mariologiczne. Choć wielu egzegetów utożsamia ową Niewiastę z Maryją, matką Jezusa, to jednak wydaje się, że wizja apokaliptyczna ,przekracza ramy takiej interpretacji”. Co ciekawe, opisana w tym fragmencie kobieta wydaje się mieć charakter ponadczasowy, zaś towarzyszące jej symbole zawierają w sobie symbolikę kosmiczną (gwiazdy) oraz arytmetyczną (liczba dwanaście). Drugą kluczową postacią jest smok, ,który staje się głównym protagonistą w Ap 12”. Autor monografii zauważa, że pierwotnie mówi się o ,jakimś smoku” - rzeczownik nie jest poprzedzony rodzajnikiem - dopiero od Ap 12,4 przed greckim $\delta \rho \alpha ́ \kappa \omega v$ pojawia się rodzajnik, zaś tajemniczy smok staje się wiadomym i konkretnym stworem. Ks. Kotecki uważa, że cały obraz przedstawiony w tym fragmencie powinien być interpretowany w kluczu symbolicznym.

Ostatni rozdział X poświęcony jest Ap 22,20 oraz epilogowi księgi Apokalipsy (22,6-21). Autor zauważa, że epilog jest fragmentem spójnym treściowo z całym dziełem Jana z Patmos. Trzeba więc stwierdzić, że jest on metatekstualny. W związku z tym, że wspomnieliśmy o charakterze liturgicznym Apokalipsy, trzeba powiedzieć, że epilog jest hymnem liturgicznym kończącym ostatnią księgę Nowego Testamentu. Do Jana w pierwszej kolejności zwraca się tu Anioł $(22,6)$, potem zaś sam Chrystus z zapewnieniem o powtórnym przyjściu. Ks. Kotecki zauważa, że błogosławieństwo zawarte w 22,7 wypowiedziane jest przez anioła, jednak nie można w żaden sposób wykluczyć, że wypowiada je też sam Chrystus. Niezwykle istotny jest wiersz 22,16 w którym pierwszy raz w całej Apokalipsie przedstawia

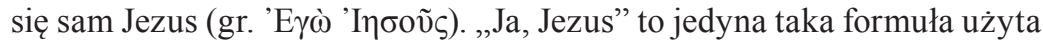
w Nowym Testamencie. Po tym przestawieniu następuje dalsza autoprezentacja Jezusa, który stosuje wobec siebie starotestamentowe symbole z Księgi Izajasza oraz określenie mesjańskie z Iz 1,1.10.

Nietypowym rozwiązaniem jest brak zakończenia w monografii ks. Koteckiego. Autor zaznacza, że dobrym rozwiązaniem jest pozostawić owe 
rozważania w formie otwartej z nadzieją, że „szkice te przyczynią się do lepszego zrozumienia wspaniałej Księgi Apokalipsy”.

„Zrozumieć Apokalipsę? Szkice egzegetyczno-teologiczne” to bardzo dobra i napisana przystępnym językiem monografia. Rzeczownik „szkice” w tytule książki daje jasną zapowiedź, że dzieło ks. Koteckiego to nie monumentalny komentarz naukowy, lecz jedynie zerknięcie na najważniejsze i najbardziej intrygujące zagadnienia działa janowego. W pierwszej kolejności książka jest swego rodzaju kompendium dla uczestników biblijnej Szkoły Dabar, którzy przemierzając wyspę Patmos, mogą sięgnąć do jej treści, niczym do własnego notatnika, zaś w drugiej kolejności każdy miłośnik dabar JHWH (דבר יהוה) znajdzie solidne opracowanie, które z pewnością przybliży mu ten trudny tekst. Ks. Kotecki zaznacza, że zadaniem tej książki nie jest poszerzanie czyjejś wiedzy, lecz poczucie klimatu apokaliptycznego świata w którym ,przewodnikiem był Jan z Patmos". Choć Apokalipsa to księga niezwykle trudna i wymagająca, do której trzeba sięgać nieustannie, to z pewnością monografia ks. Koteckiego będzie niezwykle pomocna w poznaniu i przybliżeniu treści i symboliki ostatniej księgi Nowego Testamentu. 